\title{
Vad vet vi om den ryska pappan? Utvecklingen av faderskapsnormer från ett historiskt och internationellt perspektiv
}

\author{
Pelle Åberg ${ }^{\star}$
}

Docent i statsvetenskap, Lektor vid institutionen för socialvetenskap, Ersta Sköndal högskola, och forskare vid institutionen för samhällsvetenskaper och Center for Baltic and East European Studies (CBEES), Södertörns högskola

\begin{abstract}
What do we know about fatherhood and norms concerning fatherhood in Russia? This article investigates this question using previous research and the contemporary statediscourse. Family and parenthood have been important parts of the state-discourse during the last decades due to the demographic situation in Russia. However, at the same time, fathers are more or less absent from the discourse while mothers and children are occurring frequently. With this as a background, the role of the father is examined, in the past and in the present. This is done using previous research on Soviet and Russian fatherhood, with the aid of knowledge gained through fatherhood studies in other national contexts as well as current policy documents and presidential speeches. The results show that norms concerning fatherhood are closely connected to the sociopolitical context and changes in welfare systems and in the gender contract. The development of fatherhood models differ between Russian and West European, and American, experiences. In today's Russia there are competing discourses, suggesting that the role of the father is contested. There is evidence of both a marginalized fatherhood model, a legacy from Soviet times, of the traditional breadwinner model of fatherhood as well as of a more nurturing and active type of fatherhood.
\end{abstract}

Keywords: Fatherhood, Russia, parenthood, breadwinner, active fatherhood

\section{Introduktion}

Ryssland har stått inför demografiska utmaningar under de senaste 25 åren. I genomsnitt har befolkningen minskat med en halv procent per år sedan 1991 (en minskning på totalt cirka 8 miljoner invånare). Detta har på olika sätt framställts som en demografisk kris och har fått mycket uppmärksamhet på den ryska politiska arenan. Den väg som den ryska staten primärt använt sig av för att motverka denna utveckling har varit att försöka främja ett ökat barnafödande. Barn och moderskap har fått

^Kontaktinformation: Pelle Åberg. Email: pelle.aberg@esh.se 
framskjutna placeringar i exempelvis utspel från de ryska presidenterna under åren men däremot är papporna i stort sett helt frånvarande i statliga policys och på det stora hela i den statliga diskursen. Forskningen kring ryskt faderskap är också tämligen begränsad, vilket leder fram till frågan som denna artikel ger sig i kast med: Vad vet vi egentligen om faderskap och normer kring faderskap $i$ Ryssland? För att närma sig denna fråga är det viktigt att också studera ryskt faderskap under sovjettiden då historiska arv påverkar, eller ramar in, nutida normer kring faderskap (Doherty, Kouneski \& Erickson 1998; LaRossa 1998; Marsiglio et al. 2000).

Att pappor och faderskap är mer eller mindre osynliga i ryska statliga diskurser och policys kan uppfattas som förvånande om vi betänker den forskning som visat på hur faderskap som social institution och som praktik har betydelsefulla implikationer för samhället, särskilt då pappors beteende och attityder inte bara påverkar pappornas egna fysiska och psykiska hälsa utan även barnens och mammornas hälsa (se t.ex. Kimmel 2008). Forskning har också visat att en pappa som är mer närvarande och tar en mer aktiv del i barnuppfostran och familjeliv ökar sina sociala relationer som i sin tur minskar förekomsten av missbruk i olika former likväl som benägenheten för våld i hemmet (Rossi 1984; se också Early 2001; Thaddeus \& Maine 1994). Pappor som tar sig an en aktiv och omhändertagande roll i familjen kan också positivt påverka kvinnors attityd till att skaffa fler barn (Duvander \& Andersson 2006; Hobson \& Olah 2006), vilket borde anses positivt utifrån den ryska statens agenda.

För att förstå normer kring faderskap i dagens Ryssland kan verktyg återfinnas i den tämligen omfattande forskning kring faderskap som redan finns i västra och norra Europa och USA. Samtidigt är det centralt att beakta vilka historiska avlagringar som finns och vilka normer som främjades av det sovjetiska systemet. I denna artikel kommer faderskap i Ryssland därför att studeras utifrån tidigare forskning, gällande både sovjettiden, andra nationella kontexter än den ryska och den nutida ryska situationen. För att undersöka situationen i dagens Ryssland kompletteras materialet också med policydokument och tal givna av den ryska presidenten, vilka utgör material som belyser aktuella diskurser, åtminstone statliga sådana. Slutligen exemplifieras existensen av en diskurs kring ett aktivt faderskap med material om ryska pappaskolor. Detta material kommer från intervjuer med företrädare för och dokument från de aktuella organisationerna och verksamheterna.

Artikeln inleds med en inblick i vad forskning från västra och norra Europa och USA säger om faderskap och utvecklingen av faderskapsideal över tid. Därefter vänds blicken mot den kunskap som finns kring hur faderskap utvecklades under och påverkades av det sovjetiska systemet. Slutligen diskuteras dagens ryska situation och de diskurser kring faderskap som framträder där.

\section{Faderskap i västra och norra Europa och USA}

Forskning kring faderskap började dyka upp under 1970-talet men tog fart på allvar först två decennier senare, framförallt i USA (Marsiglio et al. 2000). Intresset spred 
sig till västra Europa och de nordiska länderna och idag finns det en mängd studier kring faderskap i dessa kontexter.

Under de senaste decennierna har faderskap vanligen studerats från ett socialkonstruktivistiskt perspektiv utifrån vilket faderskap inte uppfattas som något givet eller tydligt definierat utan just som en social konstruktion. Faderskapsdiskurser är från ett sådant perspektiv uttryck för en kamp mellan olika normativa tryck från politiska, religiösa och sociala institutioner likväl som från mer personliga och privata relationer (Hobson \& Morgan 2002). Det som uppfattas som »gott» eller »lämpligt» faderskap hänger samman med historiska arv och den sociopolitiska kontexten, eller mer konkret med de ideologier och praktiker som associeras med att vara en pappa (Doherty, Kouneski \& Erickson 1998; LaRossa 1998; Marsiglio et al. 2000). Det är också på detta sätt som begreppet diskurs används i artikeln, för att beteckna de system och villkor som strukturerar hur olika aktörer talar om och handlar kring exempelvis faderskap, eller emellanåt det mer allmänna »föräldraskap». Viktigt att komma ihåg här och i resterande delar av denna artikel är att vi måste skilja på synen på och normer kring faderskap å ena sidan och pappors faktiska beteende å den andra. Det är inte på något sätt givet att beteenden överensstämmer med de normer som förfäktas eller de diskurser som existerar (Craig 2006; Kimmel 2008; Wall \& Arnold 2007).

Tidigare forskning har pekat på att synen på faderskap har förändrats över tid i många länder. Den traditionellt förhärskande papparollen i många kontexter har varit att agera som »the breadwinner», alltså att vara försörjaren och beslutsfattaren i familjen men inte vara särdeles inblandad i barnuppfostran eller hushållssysslor. Hädanefter kommer denna faderskapsmodell att benämnas »familjeförsörjarmodellen». Modellen implicerar att pappans/mannens roll primärt finns i den offentliga, inte den privata, sfären (Lamb 2000; Kimmel 2008). Detta var den vanligast förekommande faderskapsmodellen från mitten av 1800-talet fram till andra världskriget. Under den tiden ledde industrialiseringen till att allt fler män arbetade långt ifrån hemmet, vilket i sin tur ledde till att pappor var mer frånvarande i familjen.

Från 1940- till 1960-talet dominerande en faderskapsmodell som kallats för "the sex role model» i bland annat USA. Pappan fortsatte att vara den huvudsakliga försörjaren men tog här en mer aktiv roll också i barnuppfostran som en kontrollerande och disciplinerande kraft som såg till att familjen levde enligt accepterade sociala normer. För enkelhets skull kommer denna modell i resten av artikeln att benämnas »förebildsmodellen». Med andra ord var pappan inte längre lika marginaliserad $\mathrm{i}$ den privata sfären utan faderskapet skulle fungera som en brygga mellan den privata och den offentliga sfären. Dock var pappan inte heller i denna modell någon som tog del i hushållets sysslor eller var en central omhändertagande kraft vis-á-vis barnen (Kimmel 2006: 105-107).

Under 1960-talet växte emellertid en alternativ modell fram som idag är vanligt förekommande, åtminstone $\mathrm{i}$ en del länder såsom de nordiska. I denna modell är pappan mer aktiv i alla aspekter av familjelivet och tar sig an också en omhändertagande och vårdande roll gentemot barnen. Pappan har ett större fokus 
på den privata sfären jämfört med de tidigare modellerna och har ambitionen att möta såväl materiella som emotionella behov hos barnen (Atkinson \& Blackwelder 1993; Doherty, Kouneski \& Erickson 1998; Lamb 2000; LaRossa 1998; Lupton \& Barcley 1997; Pleck 1998). Detta kallas ibland för det »nya» eller »ansvarstagande» faderskapet och bygger på ett mer jämställt förhållande mellan mannen och kvinnan i familjen (Eränta \& Moisander 2011; Williams 2008). Föräldrarna förväntas dela på ansvaret för hushållet och barnuppfostran och båda ska ha såväl möjlighet som skyldighet att balansera arbets- och familjeliv. Hädanefter kommer denna modell att benämnas »den aktiva faderskapsmodellen».

I inledningen till denna artikel nämndes att när pappor engagerar sig mer $\mathrm{i}$ familjen och barnen är det inte bara något gott i sig självt utan det utgör även en bidragande faktor för att minska våld i hemmet, för att förbättra hälsan för såväl pappor som mammor och barn och för att förbättra jämställdheten mellan könen (se t.ex. Kimmel 2008; Rossi 1984). Även om faderskap och ett aktivt sådant är tydligt kopplat till familjens privata sfär så är det också relaterat till olika offentliga och samhälleliga värden.

Det könskontrakt, med vilket här avses »the gender division of labour, at work, and by implication, at home» (Gottfried 2000), som är förhärskande i ett samhälle påverkar i stor utsträckning vilka faderskapsnormer som utvecklas. Det är också möjligt att skilja mellan »officiella» könskontrakt, som inkluderar statliga policys, ideologi och lagstiftning, och "vardagliga» könskontrakt, som innefattar individers normer och rutinmässiga beteenden (Temkina \& Rotkirch 2003). Med andra ord har könskontrakt, precis som faderskap, både offentliga (t.ex. välfärdssystemet) och privata dimensioner (t.ex. familjerelationer).

Faderskap påverkas i stor utsträckning av välfärdssystemet och av socioekonomiska strukturer och processer. Exempelvis visar tidigare forskning att arbetslöshet och fattigdom hindrar ett aktivt faderskap (Doherty, Kouneski \& Erickson 1998: 287). Dessutom är klass, utbildning och socioekonomisk status av betydelse för att förstå faderskap. Medelklassmän är mer benägna att förfäkta progressiva könsnormer som påverkar deras uppfattning av faderskap och de använder också dessa attityder för att påvisa en skillnad mellan dem och män från andra klasser eller från andra kulturella kontexter (LaRossa 1998: 456; Lupton \& Barcley 1997: 15).

Av stor betydelse i detta sammanhang är de minskande födslotal och den samtida ökningen av kvinnors deltagande på arbetsmarknaden som varit delar av samhällsutvecklingen i många länder i den industrialiserade delen av världen sedan andra världskriget. Dessa utvecklingar har direkt påverkat kvinnors omhändertagande roll i den privata sfären och de nya förhållandena har gjort det nödvändigt att hitta vägar för kvinnor att kunna kombinera arbete och familj, vilket har skapat en ny funktion för välfärdsstaten. Den historiska utvecklingen av välfärdsstaten och de skillnader som finns mellan olika välfärdsregimer hänger därmed intimt samman med de olika faderskapsmodeller som diskuterats ovan genom att välfärdsregimer upprätthåller värden och normer kring kön samt definierar juridiska och ekonomiska villkor för föräldraskap. 
Tidigare forskning kring olika välfärdsregimer har emellertid i stor utsträckning negligerat könsdimensionen i analyserna av relationerna mellan arbete och välfärd (Hobson \& Morgan 2002; jfr Esping-Andersen 1990). Dock finns det undantag från detta. Exempelvis har Lewis (1992) identifierat tre olika välfärdsmodeller som ger mycket olika villkor för föräldraskap, både för mammor och pappor.

I den »starka manliga familjeförsörjarmodellen» (the strong male-breadwinner model) motarbetas kvinnligt deltagande i arbetslivet genom skattepolicys, brist på möjligheter att arbeta deltid och brist på barnomsorg. Modellen utgår från antagandet att det är kvinnan som är ansvarig för omvårdnaden och omhändertagandet av barn och familj. I denna modell definieras kvinnor som hustrur och mammor medan män definieras som arbetare och medborgare, vilket också begränsar mannen till en försörjarroll. Lewis för fram Storbritannien som ett land som kommer nära denna modell.

I den andra modellen, den »modifierade manliga familjeförsörjarmodellen» (the modified male-breadwinner model) förväntas kvinnor vara mer aktiva på arbetsmarknaden och uppbär en dubbel identitet som både mammor och arbetare. Samtidigt ska familjer kompenseras för de kostnader som följer med att föda och uppfostra barn. Välfärdstjänster rörande barnomsorg och mammaledighet är tämligen generösa, vilket gör det möjligt för kvinnor att arbeta. Samtidigt är familjestrukturerna fortsatt patriarkala och kvinnor är beroende av sina makar. Frankrike får utgöra ett exempel på denna modell.

Slutligen, i den »svaga manliga familjeförsörjarmodellen» (the weak malebreadwinner model) utformas policys på ett sådant sätt att det ska vara fördelaktigt för kvinnan att arbeta. Skattelagstiftningens utformning är en viktig del i detta. I Sverige, som lyfts fram som ett exempel på denna modell, introducerade regeringen individuell beskattning 1971, en reform som rimmar väl med denna typ av välfärdsmodell. Kännetecknen för den svaga manliga familjeförsörjarmodellen är omfattande offentlig barnomsorg, generösa villkor för föräldraförsäkring och föräldraledighet för pappor. Genom att underlätta kvinnors deltagande i arbetslivet och genom att uppmuntra ett mer aktivt faderskap ges utrymme för en mer jämställd arbetsfördelning när det gäller omhändertagande och uppfostran av barn i den privata sfären. Denna modell signalerar att kvinnor inte bara ska ses som mammor utan också som arbetare medan män ska uppfattas som pappor likväl som arbetare (Lewis 1992).

\section{Faderskap i Ryssland}

Med den ovanstående genomgången av faderskapsforskning i Västeuropa och USA kan vi nu ta oss an frågan kring vad vi vet om faderskap i Ryssland.

I jämförelse med forskningen kring faderskap i Västeuropa och USA är detta forskningsområde tämligen nytt i Östeuropa och den postsovjetiska regionen. Dock finns det en snabbt växande litteratur på området (se t.ex. Tjernova 2007; Gurko 1999, 2000; Kon 2002, 2008; Kukhterin 2000) och detsamma gäller närliggande områden såsom föräldraskap och maskulinitet (se till exempel ett flertal arbeten av Anna Temkina och Yelena Zdravomyslova). Internationell forskning om ryskt 
faderskap och närliggande teman är emellertid närapå icke-existerande (se dock Rotkirch 2000 och Utrata 2008 för två undantag). Denna artikel är ett steg i riktning mot att fylla detta hål.

\section{Sovjetiskt faderskap}

Utvecklingen av faderskapsideal har sett annorlunda ut i Ryssland i jämförelse med de kontexter som studerats i den faderskapsforskning som diskuterats ovan. Det finns de som argumenterat för att pappans roll i Ryssland, och i Östeuropa mer generellt, även före sovjettiden var svagare än vad som var fallet i Västeuropa och USA. En traditionell familjemodell i Ryssland innebar ofta hushåll som bestod av flera generationer där den äldre generationen dominerade den yngre. Även om också detta var en patriarkal modell, i likhet med vad som stod att finna i Väst, så var det inte nödvändigtvis "pappan» som var familjens överhuvud utan ofta en man från en äldre generation (Hajnal 1965; Laslett 1983).

Under sovjettiden var människors livscykler tämligen standardiserade. Om vi jämför med Västeuropa vid samma tid, eller för den delen med dagens Ryssland, så var utrymmet för mångfald i privatlivet mer begränsat i Sovjetunionen. Den privata sfären, inklusive familj, föräldraskap och barnuppfostran, var inte så privat utan kontrollerades till stor del av staten (Zdravomyslova \& Temkina 2003, 2007). Staten gjorde det privata politiskt och offentligt.

Det sovjetiska systemet och det könskontrakt som var del av det systemet påverkade synen på familj, föräldraskap och faderskap. Generellt var frågor kring demografi, fertilititet och barnafödande också framträdande i Sovjetunionen där befolkningen sågs som en nödvändig resurs för staten. Ett antal studier av fertilitetstrender genomfördes i Sovjetunionen men de studierna fokuserade enkom kvinnor. Män ansågs inte vara viktiga när det gällde beslut kring reproduktion (RivkinFish 2003: 291; Rivkin-Fish 2006; jfr Åberg 2015).

Ryska forskare har identifierat tre huvudsakliga perioder i det sovjetiska könskontraktet som inverkade på familjeliv och föräldraskap. Det finns också forskning om sovjetiskt faderskap som delvis sammanfaller med dessa perioder.

Den första perioden i det sovjetiska könskontraktet varade från revolutionen 1917 fram till tidigt 1930-talet. Under denna tid fanns emancipatoriska strävanden där en familjestruktur i vilken kvinnans plats var i köket skulle bekämpas. Samtidigt ansågs kvinnor, framförallt på landsbygden, vara i behov av ideologisk skolning, vilket legitimerade statliga interventioner i den privata sfären. Den typen av interventioner har en del forskning menat var det huvudsakliga motivet bakom emancipationsdiskursen, snarare än genuina feministiska motiv (Ashwin 2000: 5; Kukhterin 2000: 71).

Oavsett motiv ledde sovjetiska emancipationssträvanden, genom vilka en traditionell patriarkal familjestruktur underminerades, till att en betydligt högre andel kvinnor än tidigare deltog $\mathrm{i}$ arbetslivet utanför hemmet. \Den arbetande modern» var en central pelare i det sovjetiska könskontraktet (Ashwin 2000; Zdravomyslova \& Temkina 2003). Deltagande i arbetslivet skulle både frigöra kvinnor från förtryck i den privata sfären och integrera dem i samhället. För att uppnå det 
skulle den offentliga sfären ta över uppgifter rörande omhändertagande och uppfostran av barnen. Denna ambition förde exempelvis med sig att mängden offentligt drivna dagis/förskolor ökade dramatiskt (Ashwin 2000: 10). Den sovjetiska staten och kvinnan/mamman ingick en allians medan mannen/pappan knuffades ut i den offentliga sfären, som försvarare av fäderneslandet och som arbetare. Man kan säga att den sovjetiska staten tog över föräldrarollen från pappan.

Villkoren för familjelivet förändrades också på andra sätt. Kyrkliga och religiösa äktenskap förbjöds, enkla procedurer för skilsmässa introducerades och abort legaliserades (Zdravomyslova \& Temkina 2003: 304-310). Dessutom togs rätten att äga privat egendom bort, vilket var centralt då just egendomsrätten i många kontexter hade gett mannen makt över kvinnan. Mannens roll som den naturliga familjeförsörjaren var inte längre en självklarhet utan togs också den över av staten. Sammantaget innebar dessa och ett flertal andra förändringar att pappans position $\mathrm{i}$ familjen kraftigt försvagades under tidig sovjettid.

Den andra perioden, från 1930-talet till mitten av 1950-talet, var en tid av intensiv modernisering och industrialisering i Sovjetunionen. Arbetsmigration och urbanisering var viktiga processer under denna period, särskilt för män. Det blev svårare att bilda och hålla ihop familjer. Ensamma mammor på landsbygden var mycket vanligt. Den ryska ortodoxa kyrkan, som hade fungerat som en garant för mannens makt i tsarrysslands patriarkala familjestruktur, förföljdes. Det, tillsammans med politiska förföljelser, deportationer och andra världskriget, bidrog också till att alltfler pappor separerades från sina familjer (Kukhterin 2000: 78).

Behovet av arbetskraft konsoliderade också kvinnors roll som arbetare. Samtidigt fanns ett behov av att säkra en befolkningsökning vilket gjorde att barnafödande konstruerades som en plikt gentemot samhället (Rivkin-Fish 2006). Därför förbjöds också abort vid denna tid. Att sträva efter privatliv och individualitet ansågs egoistiskt och borgerligt. Staten förstärkte också denna syn bland annat genom boendepolicys som innehöll olika former av kollektivt boende (Zdravomyslova \& Temkina 2003: 310-314). På många sätt upphörde den privata sfären att existera.

Det sovjetiska könskontraktet kan sägas ha etablerat en könsordning som avsevärt underminerade förutsättningarna för en faderskapsmodell i linje med en traditionell familjeförsörjare, vilket var den dominerande modellen i väst vid denna tid.

Om vi här återvänder till Lewis välfärdstypologi som diskuterats ovan kan vi dra slutsatsen att Sovjetunionens välfärdssystem under denna andra period på flera sätt påminner om den svaga manliga försörjarmodellen. Kvinnor uppmuntrades att arbeta och de fick ta del av sociala förmåner i egenskap av arbetare snarare än i egenskap av hustru och mamma. Det fanns omfattande barnomsorg och ett generöst socialt försäkringssystem. Den här typen av modell växte faktiskt fram betydligt tidigare i Sovjetunionen än i väst där den inte dök upp förrän i slutet av 1960-talet eller tidigt 1970-tal. Konsekvenserna av denna modell för faderskap blev emellertid helt annorlunda i den sovjetiska kontexten. I västeuropeiska länder som Nederländerna och Sverige ledde dylika utvecklingar till ett mer aktivt faderskap. I Sovjetunionen hade modellen snarast den omvända effekten. Faderskap som en 
social institution blev irrelevant. I familjen var pappan marginaliserad och ibland helt frånvarande.

Orsakerna till detta kan man spekulera i. Att den traditionella försörjarrollen mer eller mindre omöjliggjordes bidrog säkerligen. Att en traditionell familjemodell i Sovjetunionen ofta bestod av flera generationer där pappan inte nödvändigtvis var familjeöverhuvudet och där den äldre generationen ofta klev in och var behjälplig i barnuppfostran och barnomsorg kan också ha förstärkt pappans marginalisering. Man kan förstås undra vad som hade blivit resultatet om denna typ av reformer hade genomförts i exempelvis de nordiska länderna vid samma tid. Som redan nämnts, skedde detta betydligt senare i den kontexten. Det kan alltså också vara en fråga om när det är »rätt» tid för normer att förändras. Denna artikel är inte rätt forum för att mer detaljerat försöka reda ut förklaringarna till de skillnader som verkar finnas mellan olika kontexter i denna fråga då det också skulle tarva en närmare analys av exempelvis de nordiska länderna.

Med den tredje perioden i det sovjetiska könskontraktet avses tiden från mitten av 1950-talet till slutet av 1980-talet. Den perioden karaktäriserades fortsatt av statens centrala roll. Dock återuppstod under denna tidsperiod ett visst avstånd mellan den privata och den offentliga sfären. Familjeliv, barnafödande, preventivmedel och barnuppfostran uppfattades nu i högre grad som områden under privat ansvar.

Under 1960- och 1970-talen började Sovjetunionen uppleva demografiska problem i form av en minskande befolkning till följd av låga födslotal, dålig folkhälsa och hög dödlighet. För att bekämpa dessa problem började staten att förespråka tidiga äktenskap och stora familjer samt att avråda från skilsmässa. Det sovjetiska könskontraktet började nu anta mer traditionella former där kvinnor, i den officiella diskursen, porträtterades som den huvudsakliga omhändertagaren av familj och barn. Emellertid förväntades hon fortfarande arbeta vilket skapade en dubbel börda. Män uppfattades fortfarande som mer eller mindre avskilda från fertilitetssidan av det demografiska problemet och de associerades med hög dödlighet, särskilt bland medelålders män (Zdravomyslova \& Temkina 2003: 314-318).

Från slutet av 1960-talet fram till mitten av 1980-talet genomfördes ett antal juridiska och sociala reformer. Bland annat infördes en skyldighet för pappor att betala underhåll efter en skilsmässa och rätt till föräldraledighet infördes för kvinnor. Pappans roll i familjen var emellertid fortsatt begränsad också under den här perioden. I praktiken var det mamman som ensam tog ansvar för alla delar av barnens uppfostran. Detta skedde ofta tillsammans med hennes egen mamma (babusjka), vilket påminner om den traditionella familjemodellen i Östeuropa som innefattade flera generationer.

Männens roll i den offentliga sfären var tydligare än i den privata. I den offentliga sfären kunde mannen säkra en position och en karriär som byggare och försvarare av landet. En mans självförverkligande förväntades alltså ha en offentlig karaktär. Faderskap var en formell plikt och mer av en möjlig distraktion från mannens verkliga plikter gentemot samhället (Tjernova 2007; Gurko 2003; Kukhterin 2000; Rotkirch 2000: 112; Zdravomyslova \& Temkina 2003: 306). 
Den maskulina identiteten byggde alltså snarare på arbete än på patriarkal makt i hemmet. Inriktningen på statliga policys och normbyggen innebar en form av demontering av den traditionella maskuliniteten främst i den privata sfären (Ashwin 2000: 13; Tjernova 2007).

Det sovjetiska systemet innebar att två av männens traditionellt sett viktigaste makttillgångar, enskild egendom och försörjarrollen, försvann. Det sovjetiska ekonomiska systemet omöjliggjorde en roll som den enda försörjaren och då en mans primära roll var knuten till hans karriär och arbete innebar avskiljandet från skyldigheter i hemmet också att pappan inte kunde fungera som vare sig omhändertagare eller $\mathrm{i}$ enlighet med förebildsmodellen (Tjernova 2008; Pascall \& Manning 2000: 242; Rodin \& Åberg 2013; se också Rivkin-Fish 2010: 707). Dessa roller hade istället övertagits av mamman och staten. Emedan moderskap politiserats, och i viss mån glorifierats, var pappans roll fortsatt höljd i dunkel (Ashwin 2000: 12). Detta förde med sig att faderskap uppfattades annorlunda än i de flesta länder i väst där faderskap fortsatt var en viktig institution. I Västeuropa och USA hade pappor en nyckelroll i den privata sfären. Mäns dominanta position i den offentliga sfären gav dem också makt i familjen som försörjare och förebild, där de förväntades fylla en kontrollerande och disciplinerande roll. Samtidigt var mamman ofta begränsad till den privata sfären.

I Sovjetunionen ersattes med andra ord det traditionella patriarkala systemet av en hegemonisk stat som tog över pappans roll som försörjare och familjens överhuvud. Mannen, maken och pappan knuffades ut ur den privata sfären och blev överflödig i hemmet (Aivazova 1998). Vad som har hänt sedan Sovjetunionens sammanbrott får nu bli ämnet för denna artikels sista avsnitt.

\section{Synen på faderskap i dagens Ryssland}

De politiska och ekonomiska reformer som genomfördes under slutet av 1980- och början av 1990-talet hade stor betydelse för familj och föräldraskap. Sovjetunionens sammanbrott och introducerandet av en mer marknadsekonomisk modell tillsammans med demokratisering av det politiska livet ledde till att familjelivet gradvis återvände till att bli en framförallt privat angelägenhet. Det förde i sin tur med sig ett bredare spektrum av attityder, normer och beteenden rörande familjeliv och föräldraroller (Zdravomyslova, Rotkirch \& Temkina 2009: 11). Forskning har hävdat att det fanns en viss normlöshet kring faderskap i Ryssland under 1990-talet vilket ansetts bero på att staten saknade ideologiska mekanismer för att kunna skapa en gemensam bild av den ideala pappan (Gurko 2000: 90). Som en följd av det kunde män i större utsträckning karva ut nya roller åt sig själva, som pappor och makar i den privata sfären. Bland mammor finns det både de som önskar ändra på det sovjetiska familjemönstret men ett mer aktivt faderskap stöter också på motstånd bland mammorna (Bezrukova 2012: 269). Bland papporna finns det en grupp som fortsatt är tämligen passiva i sina familje- och föräldraskapsroller. Det finns en annan, stark, grupp som försöker etablera en mer traditionell, dominant roll i familjen. Samtidigt finns det också en mindre grupp som tar sig an en mer omhändertagande roll i relation till familj och barn. 
Redan vid slutet av sovjeteran är det möjligt att urskilja en ganska konservativ och traditionell diskurs när det gäller könsroller och familj som ligger nära faderskapets »familjeförsörjarmodell» och på vissa sätt också »förebildsmodellen». Att staten krympte eller drog sig tillbaka efter Sovjetunionens sammanbrott och statens därpå följande oförmåga att stödja familjen, kombinerat med återinförandet av egendomsrätten, ökade kraven på män att fungera som familjens försörjare. Dessutom fanns det en diskurs som förmedlade uppfattningen att kvinnor och män under socialismen hade tvingats leva på ett sätt som stod i motsättning till deras »sanna» biologiska natur. Enligt denna diskurs var männens främsta roll i den privata sfären att vara försörjare, något som också verkar ha funnit mycket stöd bland befolkningen (Motiejunaite \& Kravchenko 2008: 43). I denna diskurs utgörs pappans roll av att disciplinera barnen och leka med dem. Kvinnor, å andra sidan, förväntas anta sin »naturliga» omhändertagande roll och ansvara för att barnens olika behov möts (Rybalko 2006: 241). Kvinnors deltagande i arbetslivet var inte längre en pelare i könskontraktet. Denna diskurs har dominerat det postsovjetiska Ryssland (Ashwin 2000) och vissa forskare har kallat det för en "patriarkal renässans» (Rybalko 2006: 240). Denna diskurs kan troligen också kopplas till den ryska ortodoxa kyrkans ökade inflytande sedan Sovjetunionens sammanbrott. Kyrkan har aktivt motsatt sig abort och homosexualitet samtidigt som den uppmuntrat ett traditionellt familjeliv (Rodin \& Åberg 2013: 26f).

Som nämndes inledningsvis i denna artikel inbegriper den ryska demografiska diskursen sedan ett antal år tal om en demografisk kris. Tal om en demografisk kris är emellertid inte ett nytt fenomen, tvärtom. Demografiska problem och betydelsen av att öka barnafödandet har utgjort delar av diskursen under i stort sett hela sovjettiden. Samtidigt finns det vissa skillnader mellan den sovjetiska och den postsovjetiska diskursen. I Sovjetunionen diskuterades låga födslotal som ett samhällsproblem på ett liknande sätt som befolkningen generellt har diskuterats som central i den geopolitiska kampen mellan nationer (jfr Ashenden 1999). Sedan 1991 har diskursen kring demografiska problem kvarstått men utöver möjliga problem för staten och samhället har den också inkluderat potentiella problem för den ryska nationen (Rivkin-Fish 2006).

Den betydelse som har tillskrivits demografiska frågor i samtida Ryssland kan exemplifieras med hur dessa frågor har varit mer eller mindre framträdande delar $\mathrm{i}$ varje tal som den ryska presidenten årligen håller till den federala församlingen (på ryska: poslanie) sedan Vladimir Putin för första gången kom till makten år $2000 .^{1}$ I ett sådant tal från 2006 sägs exempelvis följande:

Och nu det viktigaste. Vad är viktigast? På Försvarsdepartementet vet man vad som är viktigast. Det handlar om kärlek, kvinnor och barn. Om familjen. Och om det moderna Rysslands största problem - om demografi. (Putin 2006, författarens översättning)

\footnotetext{
${ }_{1}$ Ett poslanie är en viktig politisk händelse. Dessa tal hänvisas ofta till som grunden för policydokument, för det material som presenteras för parlamentsledamöter i båda kamrarna och för tal från olika ledande politiker.
} 
Utöver att vara ett exempel på betydelsen som tillskrivs demografiska frågor och den roll fertilitet och familj spelar där, visar citatet ovan också på hur kvinnor och barn presenteras som de två centrala beståndsdelarna i familjen. Detta blir än tydligare i samma poslanie när Putin explicit länkar fertilitet å den ena sidan med familjer och kvinnor (mammor) å den andra sidan. Han tar upp immigration som en möjlig dellösning till befolkningsminskningen men fortsätter på ett sätt som är typiskt för diskursen:

Men oavsett omfattning kan inte immigration lösa våra demografiska problem om vi inte skapar de rätta förutsättningarna och incitamenten för att höja födslotalen här hos oss, i vårt eget land - om vi inte skapar effektiva stödprogram för mödrar, barn och familjer. (Putin 2006, författarens översättning)

Synen på fertilitet och reproduktion som framförallt kvinnliga frågor är ett av karaktärsdragen i den ryska demografiska diskursen. Mammor hävdas bära det huvudsakliga ansvaret för att uppfostra och ta hand om barnen och mamman diskuteras som kärnan eller hörnstenen i familjen. Papporna är tydligt exkluderade från diskursen, vilket verkar vara en del av ett kulturellt arv som kan spåras bakåt i tiden, även längre tillbaks än till Sovjetunionens födelse (Aivazova 1998; Rotkirch 2000).

En sökning i centrala dokument kring demografisk policy visar att ord som »fader» (otets), »pappa» (papa) och »faderskap» (otsovstvo) inte genererar några träffar alls. ${ }^{2}$ Samma mönster återfinns också i den ryska konstitutionen (Rodin \& Åberg 2013). Om pappan diskuteras alls är det snarast i rollen som familjeförsörjare medan diskursen samtidigt pekar på svårigheterna för mannen att fylla en sådan roll till följd av hög arbetslöshet, låga löner, och så vidare (Rivkin-Fish 2003). Att vara arbetslös eller på andra sätt uppleva ekonomiska svårigheter kan utgöra hinder för att kunna fungera som försörjare, men också hinder för att bli en mer aktiv pappa (Doherty, Kouneski \& Erickson 1998: 287). En studie av Bezrukova och Rodin (kommande) visar hur bara ungefär en procent av pappor i Ryssland tar ut föräldraledighet, trots att de juridiska möjligheterna finns. Samma studie visar också att ett av de huvudsakliga hindren för att pappor ska vara mer föräldralediga i Ryssland är effekterna på hushållets ekonomi och generellt låga inkomstnivåer men där mannen oftast är den som tjänar väsentligt mer än kvinnan.

Med andra ord är diskursen kring den aktiva faderskapsmodellen inte vanligt förekommande i den ryska kontexten. Dock bör vi här komma ihåg att detta handlar om normer kring hur en pappa bör vara, vilket inte nödvändigtvis knyter an till vilken roll han tar i familjen i praxis.

Det finns emellertid tendenser som tyder på att ett mer aktivt, omhändertagande faderskapsideal också håller på att slå rot i Ryssland. Ett konkret exempel är framväxten av så kallade "pappaskolor» (papa-sjkoly) i nordvästra Ryssland (framförallt i Sankt Petersburg men även i Novgorod och verksamheter håller på att byggas

\footnotetext{
${ }^{2}$ Se till exempel Kontseptsija dolgosrotjnogo sotsialno-ekonomitjeskogo razvitija Rossijskoi Federatsii na period do 2020 goda (2008); Kontseptsija demografitjeskoj politiki do 2015 goda (2001); Kontseptsija demografitjeskoj politiki do 2025 goda (2007).
} 
upp i Petrozavodsk och Archangelsk). Här finns en plats för blivande pappor att mötas, lära sig om och diskutera frågor som har att göra med att bli pappa. Hos de som organiserar pappaskolorna finns också en tydlig ambition att främja ett aktivt, engagerat och omhändertagande faderskapsideal. Studier av dessa pappaskolor visar även på hur deras aktiviteter påverkat en mer offentlig diskurs och till och med policy och lagstiftning i Sankt Petersburgregionen. Det stöd pappaskolorna numera får från den regionala makten kan tolkas som att staten också fått upp ögonen för de potentiella positiva effekter som ett mer aktivt faderskap kan få för samhället i stort, effekter som också diskuterats tidigare i denna artikel (Åberg 2014; Åberg 2015; Åberg \& Rodin kommande 2016).

Enligt Bezrukova (2012) är majoriteten av deltagarna i pappaskolorna män som har en mer demokratisk och jämställd syn på familjerelationer än den allmänt vedertagna synen. En övervägande majoritet av deltagarna har avslutat en högre utbildning och nästan samtliga har arbete. Även om kategorier som »medelklass» är mer godtyckliga i Ryssland än i många andra kontexter så delar dessa män många karaktärsdrag med det som i väst skulle uppfattas som just medelklass. Det kan tyda på att Ryssland följer samma mönster som i väst där pappor i medelklassen är de första som tar till sig nya faderskapsideal. Detta stärks också ytterligare av forskning som visar att det i Ryssland generellt är bland pappor i den välutbildade medelklassen i större städer som ett mer aktivt faderskap och en i någon mån mer jämställd situation i familjen blir vanligare. Barnuppfostran uppfattas fortfarande som en framförallt kvinnlig uppgift men pappor är mer benägna att exempelvis vara närvarande vid förlossningen och de är mindre benägna till våld i hemmet (Asonova 2010; Kay 2006; Kon 2008; Maiofis \& Kukulin 2010).

\section{Avslutande kommentarer}

Normer kring faderskap framstår som nära knutna till den sociopolitiska och socioekonomiska kontext som studeras och förändringar i välfärdssystem och i könskontrakt påverkar faderskapet och villkoren för föräldraskap i stort.

Sovjetisk emancipationspolitik, som baserades på tanken om den arbetande modern, förändrade det tidigare könskontraktet. Mammors ökade deltagande i arbetslivet utanför hemmet ledde emellertid inte till ett mer aktivt, omhändertagande faderskap, vilket senare blev resultatet av liknande processer i väst. Istället ledde Sovjetunionens policys till att faderskapsidealet och pappans roll $\mathrm{i}$ familjen förändrades från att ha varit den huvudsakliga auktoriteten i familjen till att bli en marginaliserad social institution.

Den sovjetiska staten tog successivt alltmer över rollen som familjeförsörjare. Därmed bidrog staten till en situation där pappans roll i den privata sfären var tämligen oklar. Detta skiljer sig från erfarenheterna i väst. Även om pappor i väst också var mer inriktade på den offentliga än på den privata sfären så hade de ändå en större roll att spela i familjen, inte minst som försörjare. I den sovjetiska kontexten underminerades pappans roll som familjeförsörjare också av socioekonomiska 
förhållanden. Faderskap blev därför vare sig en grund för erkännande eller för legitimitet, varken i den privata eller i den offentliga sfären.

När Sovjetunionen föll samman blev faderskap en arena för konkurrerande diskurser i Ryssland. I vissa sammanhang och på vissa arenor fortsätter faderskap att vara marginaliserat i den statliga diskursen. Samtidigt har ett faderskapsideal där pappan ska vara den pålitlige familjeförsörjaren återkommit.

Emellertid finns också tecken på en annan typ av diskurs bland Rysslands växande urbaniserade medelklass där det talas om en mer aktiv och omhändertagande pappa. Med andra ord finns det inte en tydligt dominerande bild eller diskurs kring vad gott faderskap anses vara i dagens Ryssland.

Innan mer detaljerade analyser låter sig göras krävs fler empiriska studier av faderskap i Ryssland, både som social institution och som praktik. Exempelvis kan studier av dagens ryska välfärdssystem och dess implikationer för föräldraskap generellt och särskilt för faderskap generera viktiga insikter. Sådana studier kan ha nytta av den forskning som bland annat bedrivits av Lewis. Den typ av typologier och modeller som utvecklats inom forskningen kring välfärdssystem skulle kunna appliceras på specifika välfärdsmekanismer såsom föräldraledighet, barnomsorg och frågor om flexibla arbetstider. Även analyser av till exempel skatte- och familjelagstiftning, som tillsammans ställer upp villkor för föräldraskap och faderskap, skulle bidra till vår kunskap. Utöver att öka kunskapen om faderskap och faderskapets villkor i dagens Ryssland har dylika studier potentialen att modifiera och utveckla de existerande teoretiska och analytiska verktygen. Framtida studier får utvisa om välfärdstypologier som utvecklats i västra och norra Europa och USA fungerar för att också analysera hur välfärdssystem i Östeuropa och före detta Sovjetunionen påverkar föräldraskap idag.

\section{Litteratur}

Aivazova, Svetlana (1998) Russkie zjensjtjiny $v$ labirinte ravnopravija: Otjerki polititjeskoj teorii $i$ istorii. Moscow: RIK.

Ashenden, Samantha (1999) »Questions of Criticism: Habermas and Foucault on Civil Society and Resistance» i Samantha Ashenden \& David Owen (red.) Foucault contra Habermas. Recasting the Dialogue between Genealogy and Critical Theory. London: Sage (143-65).

Ashwin, Sara (2000) »Introduction: Gender, State and Society in Soviet and post-Soviet Russia» i Sara Ashwin (red.) Gender, State and Society in Soviet and post-Soviet Russia. London: Routledge (1-29).

Asonova, Jekaterina (2010) »Novye tsennosti v detsko-roditelskich otnosjenijach». Pro et Contra January-April: 78-93.

Atkinson, Maxine \& Blackwelder Stephen (1993) »Fathering in the $20^{\text {th }}$ Century». Fournal of Marriage and Family 55 (4): 975-86.

Bezrukova, Olga \& Johnny Rodin (kommande) »How Men Reconcile Work and Family in Contemporary Russia: The Case of Parental Leave in Saint Petersburg». Europe-Asia Studies.

Bezrukova, Olga (2012) »Praktiki otvetsvennogo otsovstva: 'Papa-sjkola' i sotsialnyj kapital». Vestnik SanktPeterburgskogo Universiteta 12 (3): 266-75.

Craig, Lyn (2006) »Does Father Care Mean Fathers Share? A Comparison of How Mothers and Fathers in Intact Families Spend Time with Children». Gender $\mathcal{E}$ Society 20 (2): 259-81.

Doherty, William, Kouneski Edward \& Erickson Martha (1998) »Responsible Fathering: An Overview and Conceptual Framework». Fournal of Marriage and Family 60 (2): 277-92.

Duvander, Ann-Zofie \& Gunnar Andersson (2006) »Gender Equality and Fertility in Sweden». Marriage $\mathcal{E}$ Family Review 39 (1-2): 121-42. 
Early, Rona (2001) »Men as Consumers of Maternity Services: A Contradiction in Terms». International Fournal of Consumer Studies 25 (2): 160-67.

Eränta, Kirsi \& Johanna Moisander (2011) »Psychological Regimes of Truth and Father Identity: Challenges for Work/Life Integration». Organization Studies 32 (4): 509-26.

Esping-Andersen, Gøsta (1990) The Three Worlds of Welfare Capitalism. Princeton: Princeton University Press.

Gottfried, Heidi (2000) »Compromising Positions: Emergent Neo-Fordism and Embedded Gender Contracts». British fournal of Sociology 51 (2): 235-59.

Gurko, Tatiana (1999) »Fenomen sovremennogo otsovstva» i Muzjtiina i zjensjijina: menjajusjtiiesia roli $i$ obrazy. Moscow: Institute of Ethnology and Anthropology, Russian Academy of Science.

Gurko, Tatiana (2000) »Variativnost predstavlenij v sfere roditelstva». Sotsiologitjeskie issledovanija 11: 90-97.

Gurko, Tatiana (2003) Roditelstvo: sotsiologitjeskij aspekt. Moscow: Institute of Sociology, Russian Academy of Science.

Hajnal, John (1965) »European Marriage Patterns in Perspective» i David Glass \& David Eversley (red.) Population in History: Essays in Historical Demography. London: Edward Arnold (101-43).

Hobson, Barbara \& David Morgan (2002) »Introduction: Making Men into Fathers» i Barbara Hobson (red.) Making Men into Fathers: Men, Masculinities and the Social Politics of Fatherhood. Cambridge: Cambridge University Press (1-24).

Hobson, Barbara \& Olah Livia (2006) »Birthstrikes? Agency and Capabilities in the Reconciliation of Employment and Family». Marriage E Family Review 39 (3-4): 197-227.

Kay, Rebecca (2006) Men in Contemporary Russia: The Fallen Heroes of Post-Soviet Change? Aldershot: Ashgate.

Kimmel, Michael S. (2006) Manhood in America: A Cultural History, 2:a upplagan. New York: Oxford University Press.

Kimmel, Michael S. (2008) The Gendered Society, 3:e upplagan. Oxford: Oxford University Press.

Kon, Igor (2002) »Menjajusjtjiesia muzjtjiny v izmenjajusjtjemsia mire» i Mikhail Malysjev (red.) Gendernyj kalejdoskop. Moscow: Academia.

Kon, Igor (2008) »Muzjkaja rol i gendernyj porjadok». Vestnik obsjtjestvennogo mnenija 16: 37-44.

Kukhterin, Sergei (2000) »Fathers and Patriarchs in Communist and Post-Communist Russia» i Sara Ashwin (red.) Gender, State, and Society in Soviet and Post-Soviet Russia. London: Routledge (71-89).

Lamb, Michael (2000) »The History of Research on Father Involvement». Marriage E Family Review 29 (2-3): 23-42.

LaRossa, Ralph (1998) »Fatherhood and Social Change». Family Relations 37 (4): 451-57.

Laslett, Peter (1983) »Family and Household as Work Group and Kin Group» i Richard Wall (red.) Family Forms in Historic Europe. Cambridge: Cambridge University Press (513-64).

Lewis, Jane (1992) »Gender and the Development of Welfare Regimes». Fournal of European Social Policy 2 (3): 159-73.

Lupton, Deborah \& Lesley Barcley (1997) Constructing Fatherhood: Discourses and Experiences. London: Sage.

Maiofis, Maria \& Ilja Kukulin (2010) »Novoe roditelstvo i ego polititjeskie aspekty». Pro et Contra, JanuaryApril: 6-19.

Marsiglio, William, Paul Amato, Randal Day \& Michael Lamb (2000) »Scholarship on Fatherhood in the 1990s and Beyond». Fournal of Marriage and Family 62 (4): 1173-91.

Motiejunaite, Akvile \& Kravchenko Zhanna (2008) »Family Policy, Employment and Gender-role Attitudes: A Comparative Analysis of Russia and Sweden». Fournal of European Social Policy 18 (1): 38-49.

Pascall, Gillian \& Manning Nick (2000) \Gender and Social Policy: Comparing Welfare States in Central and Eastern Europe and the Former Soviet Union». Fournal of European Social Policy 10 (3): 240-66.

Pleck, Joseph (1998) »American Fathering in Historical Perspective» i Karen Hansen \& Ilta Garey (red.) Families in the U.S. Kinship and Domestic Politics. Philadelphia: Temple University Press (351-62).

Putin, Vladimir (2006) »Poslanie Federalnomu Sobraniju Rossijskoj Federatsii». Rossijskaja gazeta 11 May.

Rivkin-Fish, Michele (2003) Anthropology, Demography, and the Search for a Critical Analysis of Fertility: Insights from Russia. American Anthropologist 105 (2): 289-301.

Rivkin-Fish, Michele (2006) »From 'Demographic Crisis' to 'Dying Nation': The Politics of Language and Reproduction in Russia» i Helena Goscilo \& Andrea Lanoux (red.) Gender and National Identity in Twentieth-Century Russian Culture. DeKalb, IL: Northern Illinois University Press (151-73).

Rivkin-Fish, Michele (2010) »Pronatalism, Gender Politics, and the Renewal of Family Support in Russia: Toward a Feminist Anthropology of 'Maternity Capital'». Slavic Review 69 (3): 701-24.

Rodin, Johnny \& Pelle Åberg (2013) »Fatherhood Across Time and Space. Russian Fatherhood in Perspective». Baltic Worlds 6 (3-4): 21-28.

Rossi, Alice (1984) »Gender and Parenthood». American Sociological Review 49 (1): 1-19. 
Rotkirch, Anna (2000) The Man Question. Loves and Lives in Late 20th Century Russia. Helsinki: University of Helsinki, Department of Social Policy Research Report 1/2000.

Rybalko, Ivan (2006) "'New Fathers' in Modern Russia: Men's Conception of Parenthood». Vestnik SGTY 15 (3): $238-42$.

Temkina, Anna \& Anna Rotkirch (2003) »Sovetskie gendernye kontrakty i ich transformatsija v sovremennoj Rossii» i Irina Novikovaja (red.) Gender, Kultura, Obsjtjestvo. Riga: Project Women of the Baltic.

Thaddeus, Sereen \& Maine Deborah (1994) »Too Far to Walk: Maternal Mortality in Context». Social Science and Medicine 38 (8): 1091-1110.

Tjernova, Zjanna (2007) »Model sovetskogo otsovstva: diskursivnye predpisanija» i Jelena Zdravomysleva \& Anna Temkina (red.) Rossijskij gendernyj porjadok. Saint Petersburg: European University of Saint Petersburg (138-68).

Tjernova, Zjanna (2008) Semejnaja politika v Evrope $i$ Rossii: gendernyj analiz. Saint Petersburg: Norma.

Utrata, Jennifer (2008) »Keeping the Bar Low: Why Russia's Nonresident Fathers Accept Narrow Fatherhood Ideals». Fournal of Marriage and Family 70 (5): 1297-1310.

Wall, Glenda \& Arnold Stephanie (2007) »How Involved is Involved Fathering? An Exploration of the Contemporary Culture of Fatherhood». Gender \& Society 21 (4): 508-27.

Williams, Stephen (2008) "What is Fatherhood? Searching for the Reflective Father». Sociology 42 (3): 487-502.

Zdravomyslova, Jelena \& Temkina Anna (2003) »Gosudarstvennoe konstruirovanie gendera v sovetskom obsjtjestve». Zjurnal issledovanii sotsialnoj politiki 1 (3/4): 299-322.

Zdravomyslova, Jelena \& Anna Temkina (2007) »Sovetskij etakratitjeskij gendernyj porjadok» i Jelena Zdravomysleva \& Anna Temkina (red.) Rossijskij Gendernyj Porjadok. Saint Petersburg: European University of Saint Petersburg (96-137).

Zdravomyslova, Jelena, Anna Rotkirch \& Anna Temkina (2009) »Vvedenie: Sozdanie privatnosti kak sfery zaboty, ljubvi i naemnogo truda» i Jelena Zdravomyslova, Anna Rotkirch \& Anna Temkina (red.) Novyj byt $v$ sovremennoj Rossii: gendernye issledovanija povsednevnosti. Saint Petersburg: European University of Saint Petersburg (7-32).

Åberg, Pelle \& Johnny Rodin (kommande 2016) »Civil Society and Fatherhood in the Borderlands. Promoting Active Fathers in Russian Daddy-Schools» i Katalin Fábián \& Elzbieta Korolczuk (red.) Rebellious Families: Parents' Rights Activism in Central and Eastern Europe and Russia. Bloomington: Indiana University Press.

Åberg, Pelle (2014) »Promoting Active Fathers: The Birth and Development of a Civic Initiative in Contemporary Northwestern Russia». ISTR Conference Working Paper Series, Vol. IX. Tillgänglig på: https://c.ymcdn.com/sites/istr.site-ym.com/resource/resmgr/WP2014/Aberg_Promoting_Active_Fathe.pdf. Läst 7 januari 2016.

Åberg, Pelle (2015) »Civil Society and Biopolitics in Contemporary Russia: The Case of Russian 'DaddySchools'». Foucault Studies 20: 76-95. 